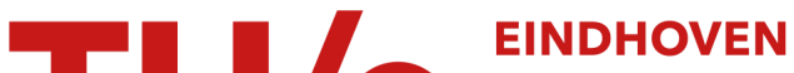

\section{Degradation of polypyrrole-modified electrodes in a chloride containing medium}

Citation for published version (APA):

Vork, F. T. A., Ubbink, M. T., Janssen, L. J. J., \& Barendrecht, E. (1985). Degradation of polypyrrole-modified electrodes in a chloride containing medium. Recueil des Travaux Chimiques des Pays-Bas, 104(7-8), 215-216. https://doi.org/10.1002/recl.19851040707

DOI:

10.1002/recl. 19851040707

Document status and date:

Published: 01/01/1985

\section{Document Version:}

Publisher's PDF, also known as Version of Record (includes final page, issue and volume numbers)

\section{Please check the document version of this publication:}

- A submitted manuscript is the version of the article upon submission and before peer-review. There can be important differences between the submitted version and the official published version of record. People interested in the research are advised to contact the author for the final version of the publication, or visit the $\mathrm{DOI}$ to the publisher's website.

- The final author version and the galley proof are versions of the publication after peer review.

- The final published version features the final layout of the paper including the volume, issue and page numbers.

Link to publication

\section{General rights}

Copyright and moral rights for the publications made accessible in the public portal are retained by the authors and/or other copyright owners and it is a condition of accessing publications that users recognise and abide by the legal requirements associated with these rights.

- Users may download and print one copy of any publication from the public portal for the purpose of private study or research.

- You may not further distribute the material or use it for any profit-making activity or commercial gain

- You may freely distribute the URL identifying the publication in the public portal.

If the publication is distributed under the terms of Article 25fa of the Dutch Copyright Act, indicated by the "Taverne" license above, please follow below link for the End User Agreement:

www.tue.nl/taverne

Take down policy

If you believe that this document breaches copyright please contact us at:

openaccess@tue.nl

providing details and we will investigate your claim. 


\section{Preliminary Communication}

Recl. Trav. Chim. Pays-Bas 104, 215-216 (1985)

$0165-0513 / 85 / 07215-02 \$ 1.00$

DEGRADATION OF POLYPYRROLE-MODIFTED ELECTRODES IN A CHLORIDE CONTAINING MEDIUM

F.T.A. Vork, M.T. Ubbink, L.J.J. Janssen and E. Barendrecht

Laboratory for Electrochemistry, Department of Chemistry, Eindhoven University of Technology, P.O. Box 513, 5600 MB Einchoven, The Netherlands

(Received July 12, 1985)

Abstract: The behaviour of a polypyrrole-modified electrode in an aqueous $0.5 \mathrm{M} \mathrm{HCl}$ solution at high anodic potentials was studied. Electrochemical experiments and ${ }^{13}$ C-NMR analysis showed a decrease in conductivity, due to the formation of $\mathrm{C}-\mathrm{Cl}$ bonds in the pyrrole ring structure.

(Received July 12th, 1985)

Since the extensive use of polypyrrole for polymer-modified electrodes ${ }^{1-4}$, several authors 5,6 have found that anodic polarization of a polypyrrole electrode in a halogen ion containing solution causes a decrease in conductivity of the polymer. Especially, oxidation of chloride ions at potentials higher than $+1.0 \mathrm{~V}$ vs. SCE causes a dramatic effect ${ }^{6}$. We studied this effect in an aqueous solution of hydrochloric acid by electrochemical techniques and by ${ }^{13} \mathrm{C}-\mathrm{NMR}$ measurements.

\section{Experimental}

The polypyrrole films were formed on a platinum disc of ca. $0.5 \mathrm{~cm}^{2}$ from an aqueous solution of $0.1 \mathrm{M} \mathrm{LiClO}_{4}$ with 1 vol. $-\%$ (ca. $0.14 \mathrm{M}$ ) pyrrole. The films were deposited either under potentiostatic conditions $(\mathrm{E}=+600 \mathrm{mV}$ vs. SCE) or under galvanostatic conditions $\left(i=2 \mathrm{~mA} / \mathrm{cm}^{2}\right)$. The film thickness was controlled by measuring the charge, used to form the film (since $\rho=$ $1.48 \mathrm{~g} / \mathrm{cm}^{3}, 100 \mathrm{mc} / \mathrm{cm}^{2}$ charge corresponds to $0.28 \mu \mathrm{m}$ thickness ${ }^{2,4}$,.

The voltametric experiments for an electrode covered with a polypyrrole film in an aqueous $0.5 \mathrm{M} \mathrm{HCl}$ solution at $25^{\circ} \mathrm{C}$ were carried out in a three-compartment cell. A saturated calomel electrode (SCE) was used as the reference electrode. The voltammograms were recorded at a scan rate of $10 \mathrm{mV} / \mathrm{s}$.

Results

Figure 1 shows characteristic $i-E$ curves for a polypyrrole electrode in $0.5 \mathrm{M} \mathrm{HCl}$. During the first anodic sweep, indicated by 1 in the figure, a peak is detected at $950 \mathrm{mV}$ vs. SCE. It has been found that this is caused by oxidation of the polypyrrole backbone. The peak at $1200 \mathrm{mV}$ during the first anodic sweep is caused by oxidation of chloride ions, because in a similar experiment with $0.5 \mathrm{M} \mathrm{H}_{2} \mathrm{SO}_{4}$ as electrolyte this peak was not present. No reduction current is observed during the cathodic sweep. During the second anodic sweep, also starting at 900 mV, the current was much smaller than during the first anodic sweep, and at potentials higher than $1600 \mathrm{mV}$ oxidation of water to oxygen occurs at the polypyrole/platinum interface resulting in oxygen bubble formation and peeling of the polymer film from the platinum substrate. The chloride concentration remains practically constant during the sweep experiments. The decrease in the height of the peak at $1200 \mathrm{mV}$ may be caused by either increase of electrode resistance or decrease in number of active sites for the oxidation of chloride ions or by both. The effect of the anodic polarization of a polypyrrole electrode in a chloride containing medium on its conductivity was studied. The potential difference between the working electrode and the counter electrode in a one-compartment electrolysis cell was measured as a function of the time of polypyrrole film formation. The film was formed galvanostatically at a current density of $2 \mathrm{~mA} / \mathrm{cm}^{2}$ on a Pt-substrate and on polypyrrole films which were already present on a Pt substrate. 
Curve $A_{1}$ of figure 2 shows the potential difference vs. time curve during the formation of the first layer of polypyrrole on a Pt-substrate. After a $5 \mathrm{~min}$. polarization the polypyrrole electrode was removed from the $\mathrm{ClO}_{4}^{-}$ pyrrole formation solution, rinsed and dried. Then a second layer of polypyrrole was formed on the electrode; the $\Delta \mathrm{E}$ vs. $t$ curve is given by $B_{1}$ of figure 2: the potential difference has been increased by ca. $13 \%$.

Curve $B_{2}$ of figure 2 shows the result of an experiment when, between the formation of the first (curve $\mathrm{A}_{2}$ ) and second layer of polypyrrole, the electrode was polarized in $0.5 \mathrm{M} \mathrm{HCl}$ from 900 to $1500 \mathrm{mV}$ vs. SCE at a scan rate of $10 \mathrm{mV} / \mathrm{s}$. The increase in $\mathrm{E} \mathrm{Vs}$. time may be caused by formation of atomic chlorine which reacts with the newly formed polypyrrole. During the formation of the second layer chloride ions are present in the pores of the first polypyrrole layer. It can be concluded that by the anodic polarization in $0.5 \mathrm{M} \mathrm{HCl}$ the potential difference has been increased by more than $30 \%$. From this result and the voltametric behaviour of a polypyrrole electrode in $0.5 \mathrm{M} \mathrm{HCl} \mathrm{(Fig.} \mathrm{1)}$ it follows that the decrease in conductivity may be caused by distortion of the $\pi$-system of conjugated double bonds of the polymer, due to addition of chlorine to the carbon backbone. The "chlorinated" polymer was investigated by ${ }^{13}$ C-NMR technique (using magic angle spinning). The spectrum of figure 3 was obtained using a delrin spinner. The spectral range between 100 and $80 \mathrm{ppm}$ from TMS was obscured. The spectrum between 110 and $140 \mathrm{ppm}$ may be contributed to the polypyrrole backbone ${ }^{7}$. The peaks at 69 and $30 \mathrm{ppm}$ probably indicate covalent $\mathrm{C}-\mathrm{Cl}$ bonds in the chlorinated polypyrrole.

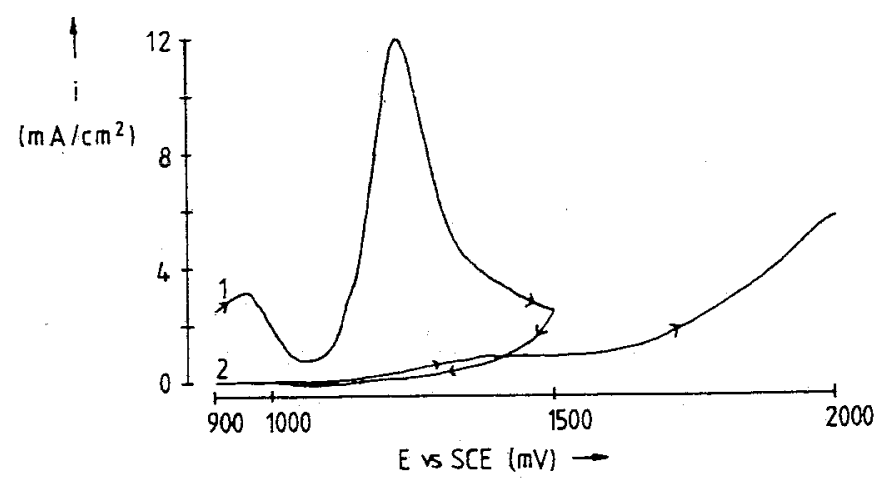

Fig. 1. i-E curve of a $1.68 \mathrm{\mu m}$ thick polypyrrole film on Pt in $0.5 \mathrm{M} \mathrm{HCl} / \mathrm{H}_{2} \mathrm{O}$.
Conclusion

Anodic polarization of polypyrrole films in a solution with chloride ions leads to a degradation of the polymer due to the addition of chlorine to the pyrrole ring structure. The chlorine atoms are covalently bound to the carbon atoms.

\section{References}

1. A.F. Diaz, K.K. Kanazawa and G.P. Gardini, J. Chem. Soc. Chen. Commun., 653 (1979).

2. R.C.M. Jakobs, L.J.J. Janssen and E. Barendrecht, Recl. Trav. Chim. Pays-Bas 103, 275 (1984).

3. R.C.M. Jakobs, Thesis, Eindhoven University of Technology (1984).

4. A.F: Diaz and K.K. Kanazawa in J. Miller (ed.), "Extended Linear Chain Compounds", vol. 3, Plenum, New York, 417 (1982).

5. T. Inoue and $T$. Yamase, BuI1. Chem. Soc. Jpn., 56, 985 (1983).

6. R.A. Bull, F.-R. Fan and A.J. Bard, J. Electrochem. Soc., 131, 687 (1984).

7. J. Scott, P. Pfluger, T.C. Clarke and G.B. Street, Po1ym. Prepr, , 23, 119 (1982).

\section{Acknowledgement}

The authors are grateful to dr.ir. J.W. de Haan for the interpretation of the ${ }^{13} \mathrm{C}-\mathrm{NMR}$ spectrum.

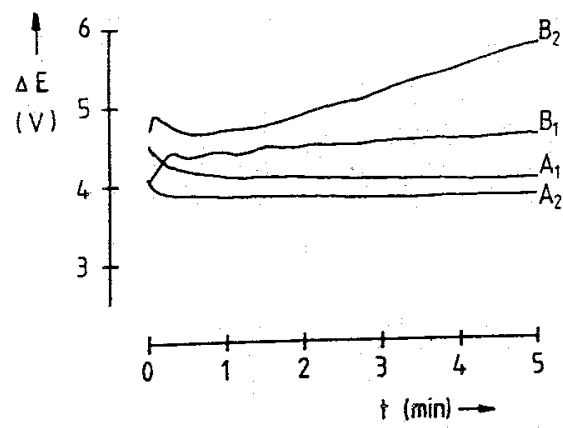

Fig. 2. $\Delta E$ vs. $t$ curves for polypyrrole formation on a platinum disc (A), on an already formed polypyrrole layer (B), with (subscript 2) and without (subscript 1) "chlorination".

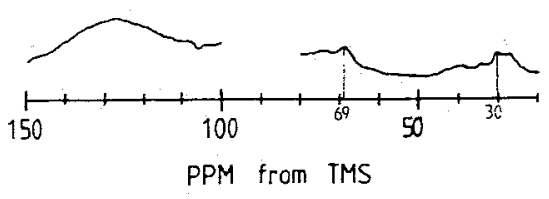

Fig. $3 .{ }^{13}$ C-NMR spectrum of polypyrrole, after "chlorination" in $0.5 \mathrm{M} \mathrm{HCl}$. 